\title{
Treatment of old landfill leachate with high ammonium content using aerobic granular sludge
}

\author{
Yanan Ren ${ }^{1}$, Fernanda Ferraz ${ }^{2}$, Abbass Jafari Kang ${ }^{1}$ and Qiuyan Yuan ${ }^{1 *}$ (D)
}

\begin{abstract}
Background: Aerobic granular sludge has become an attractive alternative to the conventional activated sludge due to its high settling velocity, compact structure, and higher tolerance to toxic substances and adverse conditions. Aerobic granular sludge process has been studied intensively in the treatment of municipal and industrial wastewater. However, information on leachate treatment using aerobic granular sludge is very limited.

Methods: This study investigated the treatment performance of old landfill leachate with different levels of ammonium using two aerobic sequencing batch reactors (SBR): an activated sludge SBR (ASBR) and a granular sludge SBR (GSBR). Aerobic granules were successfully developed using old leachate with low ammonium concentration (136 mg L $\mathrm{L}^{-1} \mathrm{NH}_{4}^{+}-\mathrm{N}$ ).

Results: The GSBR obtained a stable chemical oxygen demand (COD) removal of $70 \%$ after 15 days of operation; while the ASBR required a start-up of at least 30 days and obtained unstable COD removal varying from 38 to $70 \%$. Ammonium concentration was gradually increased in both reactors. Increasing influent ammonium concentration to $225 \mathrm{mg} \mathrm{L}^{-1} \mathrm{~N}$, the GSBR removed $73 \pm 8 \%$ of COD; while COD removal of the ASBR was $59 \pm 9 \%$. The GSBR was also more efficient than the ASBR for nitrogen removal. The granular sludge could adapt to the increasing concentrations of ammonium, achieving $95 \pm 7 \%$ removal efficiency at a maximum influent concentration of 465 $\mathrm{mg} \mathrm{L}^{-1} \mathrm{~N}$. Ammonium removal of $96 \pm 5 \%$ was obtained by the ASBR when it was fed with a maximum of 217 $\mathrm{mg} \mathrm{L}^{-1} \mathrm{NH}_{4}^{+}$-N. However, the ASBR was partially inhibited by free-ammonia and nitrite accumulation rate increased up to $85 \%$. Free-nitrous acid and the low biodegradability of organic carbon were likely the main factors affecting phosphorus removal.
\end{abstract}

Conclusion: The results from this research suggested that aerobic granular sludge have advantage over activated sludge in leachate treatment.

Keywords: Activated sludge, Aerobic granular sludge, Landfill leachate, Free-ammonia, Nutrients removal, Organic matter removal, Phosphorus removal, Sequencing batch reactors, Simultaneous nitrification-denitrification

\section{Background}

Landfilling is used worldwide as a strategy for municipal solid waste (MSW) disposal. Modern landfills offer a safe final disposal of MSW; however, when the liquids (e.g. precipitation, water content of the waste, melted snow) seep through the waste, it generates a wastewater called leachate. Among its constituents, there are heavy metals,

\footnotetext{
*Correspondence: qiuyan.yuan@umanitoba.ca

'Department if Civil Engineering, University of Manitoba, 15 Gillson St., Winnipeg, MB R3T 5V6, Canada

Full list of author information is available at the end of the article
}

dissolved solids, ammonia, biodegradable, and refractory organic matter. To prevent impacts on the environment and human health, leachate must be collected from the landfills and treated. According to the biodegradation stage of MSW, the concentrations of these compounds may vary and leachate can be classified as old or young. The latter refers to leachates containing a high amount of volatile fatty acids (VFAs), whereas old leachates are mostly constituted by refractory organic matter (as humic substances) and high ammonia nitrogen concentrations [1]. Biological processes have been used worldwide to treat 
leachate. They were particularly effective for the treatment of young leachate containing easily biodegradable organic matter [1-3]. However, there are concerns about the application of biological processes for the old leachate treatment, which contains high concentrations of ammonium nitrogen and refractory organic matter [1]. Application of chemical treatments especially advanced oxidation processes (AOP) such as sulfate radical [4] and Fenton [5] were found effective to reduce the refractory organic content of old leachate. Despite the good results, chemical methods typically need to be combined to produce a treated effluent in accordance with restricted discharge limits. Consequently, its application may be limited by the high operational costs related to energy and chemicals consumption [1]. Certain strategies may be adopted upon the feasibility of the old leachate treatment by biological processes, including pretreatments and co-treatment with domestic wastewater. Chemlal et al. [6] found that AOP as a pre-treatment could enhance the performance of an aerobic bioreactor by increasing the biodegradability of the refractory fractions. The AOP-bioreactor allowed an abatement of $90 \%$ of biological oxygen demand (BOD) and 87\% of COD from an old leachate. According to Yuan et al. [7] pre-treatment of old leachate via air stripping followed by co-treatment with wastewater in an aerobic SBR $\left(\mathrm{V}_{\text {leachate }} / \mathrm{V}_{\text {wastewater }}=2.5 \%\right)$ obtained $87 \%$ and $100 \%$ of COD and phosphorus removal, respectively. Similar results have been reported in other research works $[8,9]$. However, increasing volumetric ratio of the air-stripped leachate (up to 50\%) was found to influence nutrient removal in both aerobic and anaerobic co-treatment of leachate and wastewater [10].

Recent studies have discussed the treatment of different industrial wastewaters using aerobic granular sludge (AGS) and reported their higher tolerance to toxic substances and adverse conditions compared to the activated sludge process [11, 12]. However, information on leachate treatment using AGS is very limited. In a study which is the only one in this area, aerobic granular sludge obtained maximum removals of $83 \%$ and $92 \%$ for COD and ammonium from raw old leachate, respectively [13].

Considering that the literature is lacking information regarding leachate treatment by AGS, this study aimed to assess old leachate treatment by AGS in comparison with the activated sludge process. The study was performed using two SBR, an activated sludge SBR (ASBR) and an aerobic granular sludge SBR (GSBR). The reactors were evaluated based on the organic matter and nutrient removal efficiencies.

\section{Methods}

\section{Experimental set-up}

The GSBR consisted of a plexiglass cylinder with a $12-\mathrm{cm}$ internal diameter, the height of $45-\mathrm{cm}$ and the total volume of $5 \mathrm{~L}$, whereas the working volume was
$3 \mathrm{~L}$ (Fig. 1a). The ASBR consisted of a $5 \mathrm{~L}$ glass jar, plexiglass cylinder having a $15-\mathrm{cm}$ diameter and $30-\mathrm{cm}$ height, whereas the working volume was $3 \mathrm{~L}$ (Fig. 1b). The reactors were inoculated with $1 \mathrm{~L}$ of activated sludge collected from a full-scale wastewater treatment plant (South End Water Pollution Control Centre in Winnipeg, MB, Canada). For both the ASBR and the GSBR, at each cycle $1.5 \mathrm{~L}$ of supernatant (treated effluent) was withdrawn from the reactors and $1.5 \mathrm{~L}$ of fresh feed was pumped into them, keeping a working volume of $3 \mathrm{~L}$ and an exchange ratio of $50 \%$.

The SBRs were provided with an up-flow feed from the bottom of the apparatus. Aeration was provided by a fine air diffuser and a flow meter controlled the airflow at $3 \mathrm{~L} \mathrm{~min}{ }^{-1}$ resulting in superficial air velocity of $0.44 \mathrm{~cm} / \mathrm{s}$. The $\mathrm{pH}$ of

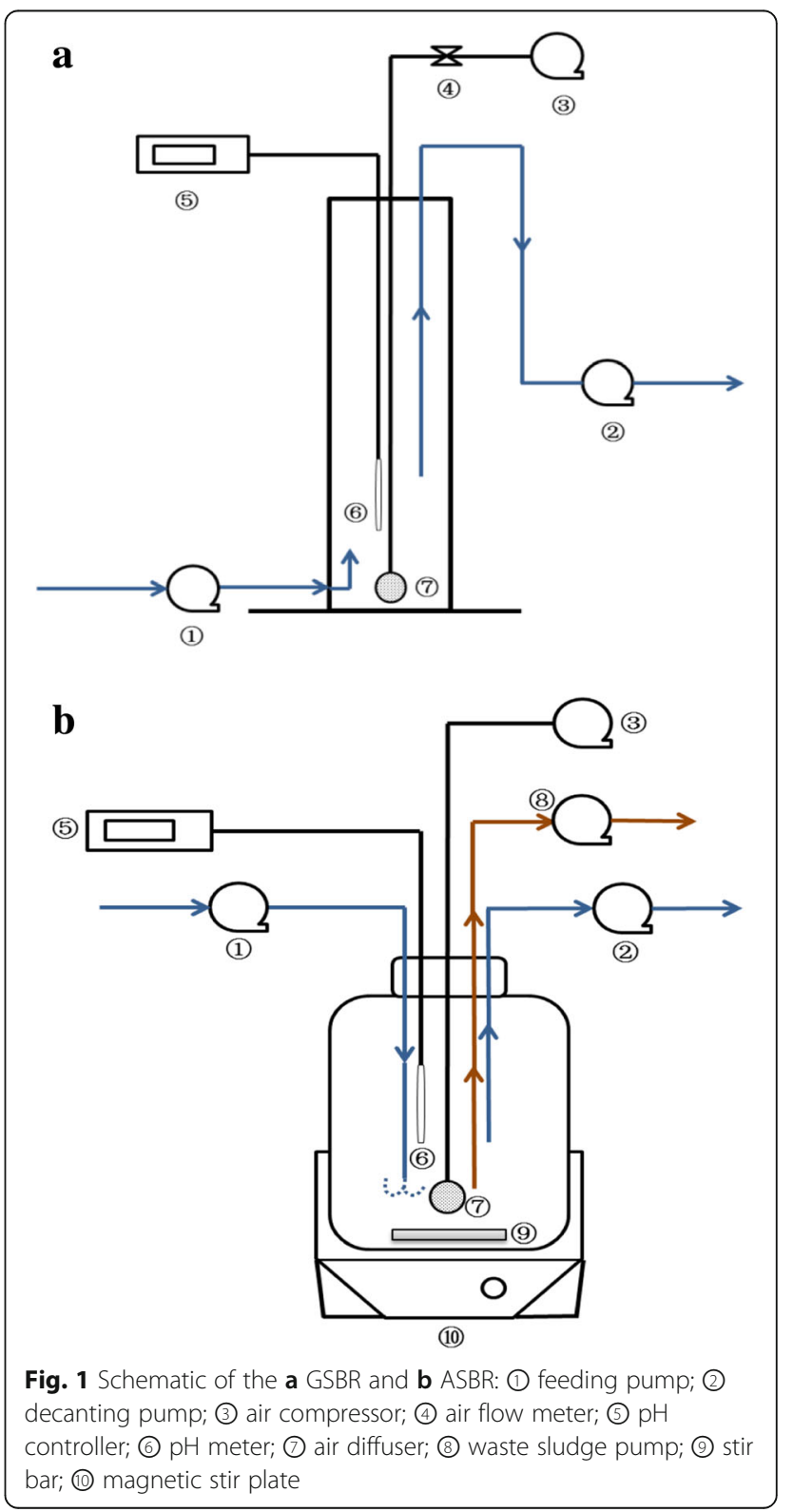


both reactors was kept greater than 6.5 during the aerobic/ anaerobic reaction time using sodium bicarbonate solution.

\section{Operation of reactors}

The reactors were operated at 3 cycles per day ( $8 \mathrm{~h}$ each cycle), at room temperature $\left(20 \pm 2{ }^{\circ} \mathrm{C}\right)$. For the GSBR, each cycle consisted of a 30-min feeding period, 1.5-h anoxic/anaerobic period, 5.75-h aerobic period, 5-min settling period, 12-min decanting period and 3-min idle phase. For the ASBR, each cycle consisted of a 30-min feeding period, $1-\mathrm{h}$ anoxic/anaerobic mixing period, 5.5-h aerobic period, 40-min settling period, 12-min decanting period, and 3-min idle phase. At the end of the aerobic phase, $30 \mathrm{ml}$ of the ASBR mixed liquor was eliminated to obtain SRT of 30 days. However, sludge retention time (SRT) of granular sludge was not controlled and biomass was only wasted via effluent solids.

\section{Synthetic old landfill leachate wastewater}

A synthetic old landfill leachate was prepared with tannic acid, which was used to simulate the refractory organic matter content of old leachates [14-16]. Additionally, macro and micronutrients were dissolved in tap water (Table 1). For every cycle, $20 \mathrm{~L}$ of fresh feed was prepared and stored in a cold chamber at $4{ }^{\circ} \mathrm{C}$.

The ammonium nitrogen concentration in the influents was gradually increased in accordance with the increasing dosages of $\mathrm{NH}_{4} \mathrm{Cl}$ in the feed of both reactors. The nitrogen loads varied from $0.42 \pm 0.04 \mathrm{~kg} \mathrm{~m}^{-3} \mathrm{~d}^{-1}$ $\left(139 \pm 14 \mathrm{mg} \mathrm{L}^{-1}\right)$ to $1.39 \pm 0.14 \mathrm{~kg} \mathrm{~m}^{-3} \mathrm{~d}^{-1}$ $\left(465 \pm 46 \mathrm{mg} \mathrm{L}^{-1}\right)$ for the GSBR and from $0.41 \pm 0.03 \mathrm{~kg} \mathrm{~m}^{-3} \mathrm{~d}^{-1}\left(136 \pm 9 \mathrm{mg} \mathrm{L}^{-1}\right)$ to $0.65 \pm 0.08 \mathrm{~kg} \mathrm{~m}^{-3} \mathrm{~d}^{-1}\left(217 \pm 26 \mathrm{mg} \mathrm{L}^{-1}\right)$ for the ASBR.

\section{Sampling and analytical methods}

Samples were taken regularly from influent and effluent, being filtered $(0.45 \mu \mathrm{m})$ before the physico-chemical analyses. Dissolved phosphate, total ammoniacal nitrogen (TAN), nitrate, and nitrite concentrations were

Table 1 Composition of synthetic old landfill leachate

\begin{tabular}{|c|c|c|c|}
\hline \multicolumn{2}{|c|}{ Organic and Inorganic Compounds } & \multicolumn{2}{|l|}{ Trace metal solution } \\
\hline Components & Per litre & Components & Per litre \\
\hline Tannic acid & $200 \mathrm{mg}$ & $\mathrm{CoSO}_{4} \cdot 7 \mathrm{H}_{2} \mathrm{O}$ & $150 \mathrm{mg}$ \\
\hline $\mathrm{NaCl}$ & $2000 \mathrm{mg}$ & $\mathrm{H}_{3} \mathrm{BO}_{4}$ & $50 \mathrm{mg}$ \\
\hline $\mathrm{CaCl}_{2}$ & 700 mg & $\mathrm{ZnSO}_{4} \cdot 7 \mathrm{H}_{2} \mathrm{O}$ & $50 \mathrm{mg}$ \\
\hline $\mathrm{NaHCO}_{3}$ & $2000 \mathrm{mg}$ & $\mathrm{CuSO}_{4} \cdot 5 \mathrm{H}_{2} \mathrm{O}$ & $40 \mathrm{mg}$ \\
\hline $\mathrm{NaOH}$ & $297 \mathrm{mg}$ & $\mathrm{MnSO}_{4} \cdot 7 \mathrm{H}_{2} \mathrm{O}$ & $500 \mathrm{mg}$ \\
\hline $\mathrm{K}_{2} \mathrm{HPO}_{4}$ & $32.5 \mathrm{mg}$ & $\left(\mathrm{NH}_{4}\right)_{6} \mathrm{Mo}_{7} \mathrm{O}_{24} \cdot 4 \mathrm{H}_{2} \mathrm{O}$ & $50 \mathrm{mg}$ \\
\hline $\mathrm{NH}_{4} \mathrm{Cl}$ & $120-500 \mathrm{mg}$ & $\mathrm{Al}_{2}\left(\mathrm{SO}_{4}\right)_{3} \cdot 16 \mathrm{H}_{2} \mathrm{O}$ & $30 \mathrm{mg}$ \\
\hline \multirow[t]{2}{*}{ Trace metal } & $0.02 \mathrm{ml}$ & $\mathrm{NiSO}_{4} \cdot 6 \mathrm{H}_{2} \mathrm{O}$ & $500 \mathrm{mg}$ \\
\hline & & $96 \% \mathrm{H}_{2} \mathrm{SO}_{4}$ & $1 \mathrm{ml}$ \\
\hline
\end{tabular}

measured by flow-injection analysis using a Lachat Instrument QuikChem 8500. Soluble COD (SCOD) was measured by Hach kits. Mixed liquor suspended solids (MLSS), mixed liquor volatile suspended solids (MLVSS), and sludge volumetric index (SVI) were quantified at 5 and $30 \mathrm{~min}$ according to [17].

The biomass of both granular and activated sludge was characterized in terms of particle size, SVI, and extracellular polymeric substances (EPS). Sludge particle size was determined by a Malvern Mastersizer 2000 analyzer. EPS were extracted from sludge by $\mathrm{NaOH}$ and formaldehyde method [18]. Protein and polysaccharides concentrations were measured by the modified Lowry assay kit and phenol-sulfuric acid colorimetric method, respectively [19].

Free-ammonia (FA) concentration was calculated by the Eq. 1, whereas free-nitrous acid (FNA) concentration was determined using Eq. 2 [20]. Total nitrogen (TN) was determined by the summation of $\mathrm{NH}_{4}-\mathrm{N}, \mathrm{NO}_{2}-\mathrm{N}$, and $\mathrm{NO}_{3}-\mathrm{N}$ [21]. Full nitrification, nitrite accumulation rate (NAR), denitrification efficiency (DE), and simultaneous nitrification-denitrification (SND) were determined by the Eqs. 3-5 [13] and Eq. 6 [22], respectively. The overall efficiencies of organic matter and nutrients removal were determined by the Eq. 7 [21].

$$
\begin{aligned}
& \mathrm{FA}\left(\mathrm{mgL}^{-1}\right)=17 / 14^{*} \frac{\mathrm{NH}_{4}^{+} \times 10^{\mathrm{pH}}}{\exp (6334 / 273+\mathrm{T})+10^{\mathrm{pH}}} \\
& F N A\left(\mathrm{mgL}^{-1}\right)=46 / 14^{*} \frac{\mathrm{NO}_{2}^{-}}{\mathrm{Ka}^{*} 10^{\mathrm{pH}}}
\end{aligned}
$$

$$
\text { FullNitrification (\%) }=100^{*}\left(\frac{\mathrm{NO}_{3 \text { effluent }}^{-}}{\mathrm{NH}_{4 \text { removed }}^{+}}\right)
$$

$$
N A R(\%)=100^{*}\left(\frac{N O_{2}^{-} \text {effluent }}{N O_{x}^{-} \text {effluent }}\right)
$$

$$
\begin{aligned}
& D E(\%)=100^{*}\left(1-\frac{\mathrm{NO}_{\mathrm{x}}^{-} \text {accumulated }}{\mathrm{TN}_{\text {Influent }}-\mathrm{TN}_{\text {effluent }}}\right) \\
& \operatorname{SND}(\%)=100^{*}\left(1-\frac{\mathrm{NO}_{\mathrm{x}}^{-} \text {accumulated }}{N H_{4}^{+} \text {removed }}\right) \\
& \text { Efficiency }(\%)=100^{*}\left(\frac{\mathrm{C}_{\text {influent }}-\mathrm{C}_{\text {effluent }}}{\mathrm{C}_{\text {Influent }}}\right)
\end{aligned}
$$

where $\mathrm{C}$ represents the concentration of $\mathrm{COD}, \mathrm{TN}$, $\mathrm{NH}_{4}-\mathrm{N}$, or phosphorus. 


\section{Statistical analysis}

An analysis of variance (ANOVA) was performed to compare the performances of the aerobic reactors treating old leachate.

\section{Results and discussions}

\section{Biomass characteristics}

The GSBR and the ASBR were operated for 200 days. The ASBR was inoculated with $3430 \mathrm{mg} \mathrm{L}^{-1}$ of MLSS, but this value decreased to $1550 \mathrm{mg} \mathrm{L}^{-1}$ during a startup period of 30 days. The activated sludge presented good settling properties: the values of $\mathrm{SVI}_{5}$ and $\mathrm{SVI}_{30}$ were $45 \pm 1.8 \mathrm{ml} \mathrm{g}^{-1}$ and $42 \pm 8 \mathrm{ml} \mathrm{g}^{-1}$, respectively. According to Metcalf and Eddy [23], good settleability was observed when the sludge presented $\mathrm{SVI}_{30}$ values smaller than $150 \mathrm{ml} \mathrm{g}^{-1}$.

The GSBR was inoculated with activated sludge at MLSS concentration of $4030 \mathrm{mg} \mathrm{L}^{-1}$. As granulation was developed, the MLSS concentration in the GSBR was gradually increased, reaching an average of $8070 \pm 615 \mathrm{mg} \mathrm{L}^{-1}$ after 100 days. This value was maintained along with time, whereas the MLVSS represented about $86 \%$ of the MLSS concentration. The average size of the activated sludge was $118 \mu \mathrm{m}$ and it increased up to $307 \mu \mathrm{m}$ in approximately three weeks as the AGS was developed. Great settling properties were observed as the AGS was formed: the $\mathrm{SVI}_{5^{-}}$ decreased from the initial value of $45 \pm 1.8 \mathrm{ml} \mathrm{g}^{-1}$ to $25 \pm 3.5 \mathrm{ml} \mathrm{g}^{-1}$.

Regarding EPS analysis, protein concentration (PN) in both reactors was quite similar: $30.75 \mathrm{mg} \mathrm{g}^{-1}$ VSS for the GSBR and $33.59 \mathrm{mg} \mathrm{g}^{-1}$ VSS for the ASBR (Table 2). However, the difference between the two types of sludge was highlighted by the polysaccharide (PS) concentration. Due to the intrinsic characteristics of granulation, i.e., granules backbone being constituted by PS [18], the PS concentration was higher in the GSBR than in the ASBR. The ratio PN/PS was on average 0.60 for the GSBR and 0.75 for the ASBR. The preponderance of PS over $\mathrm{PN}$ is associated with the hydrophilic properties of microbial aggregates [24].

\section{COD removal}

The influent COD concentrations were similar in both reactors, ranging from 448 to $654 \mathrm{mg} \mathrm{L}^{-1}$. As shown in Fig. 2, the GSBR was much more efficient in removing the COD rather than the ASBR. In other words, the

Table 2 The average PN, PS concentration, and their ratio in GSBR and ASBR

\begin{tabular}{llll}
\hline Biomass & $\begin{array}{l}\text { PN } \\
\left(\mathrm{mg} \mathrm{L}^{-1}\right)\end{array}$ & $\begin{array}{l}\text { PS } \\
\left(\mathrm{mg} \mathrm{L}^{-1}\right)\end{array}$ & PN/PS \\
\hline Aerobic granular sludge & 30.80 & 70.13 & 0.60 \\
Activated sludge & 33.60 & 49.55 & 0.75 \\
\hline
\end{tabular}

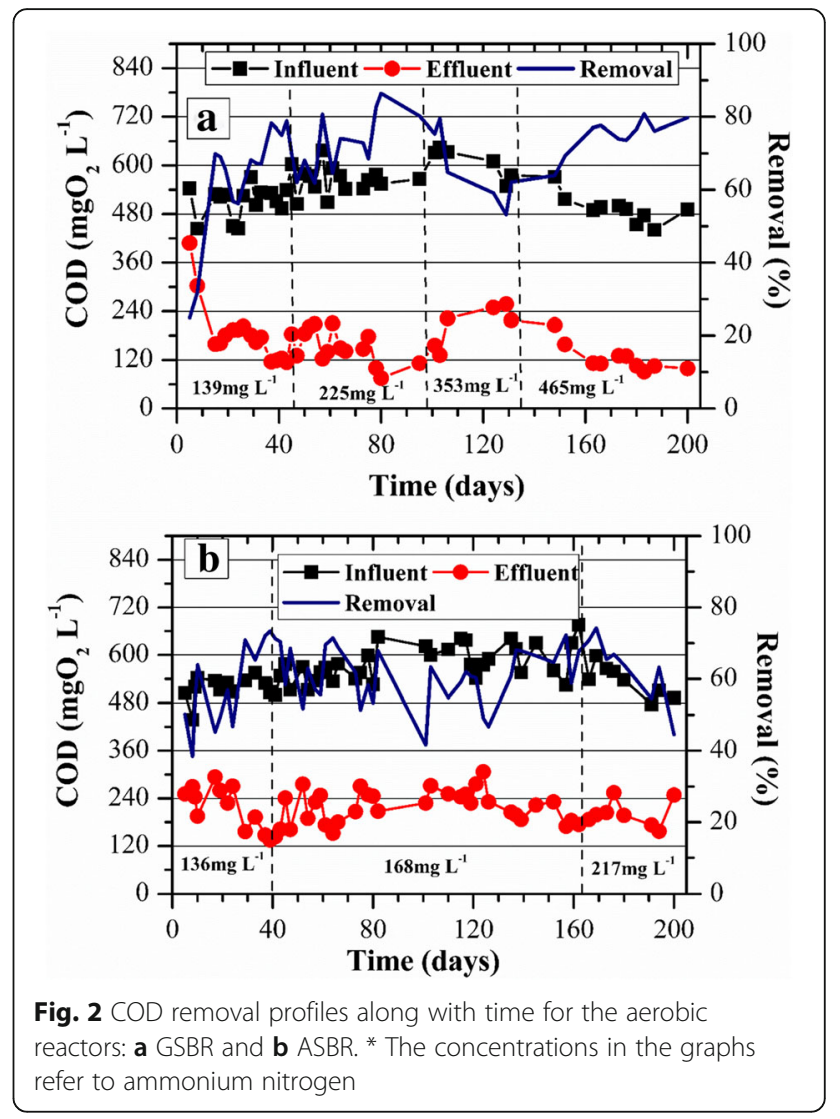

granular sludge could tolerate higher concentrations of influent COD and ammonium nitrogen than those applied to the ASBR. As shown in Fig. 2a, after 15 days the GSBR was already removing $70 \%$ of COD, maintaining the stable removal efficiency in $73 \pm 8 \%$ while the influent ammonium nitrogen was up to $225 \pm 21 \mathrm{mg} \mathrm{L}^{-1}$. When the influent ammonium nitrogen concentration was increased to $450 \mathrm{mg} \mathrm{L}^{-1}$, COD removal decreased to $55 \pm 8 \%$. However, the granular sludge recovered its performance in maintaining a COD removal efficiency of $66 \pm 12 \%$. It was clear that the GSBR could tolerate a high ammonium nitrogen concentration of $465 \pm 46 \mathrm{mg} \mathrm{L}^{-1}$. According to the ANOVA results, the differences among the GSBR removal efficiencies were statistically significant $(P$-value $=0.02$ at $\alpha=0.05)$.

In contrast to the GSBR, the ASBR did not present a stable COD removal during the first 30 days of the startup where the efficiencies varied from 38 to $70 \%$ (Fig. 2b). While the influent ammonium nitrogen concentration was $136 \mathrm{mg} \mathrm{L}^{-1}$, COD removal was $59 \pm 12 \%$. As the ammonium nitrogen was slightly increased to $168 \mathrm{mg} \mathrm{L}$ ${ }^{-1}$, the biomass could tolerate such concentration and COD removal was slightly increased to $62 \pm 8 \%$. At the last stage of the experiment, where ammonium nitrogen was increased to $217 \mathrm{mg} \mathrm{L}^{-1}$, COD removal slightly decreased to $59 \pm 9 \%$. According to the ANOVA results, 
the differences among the ASBR removal efficiencies were random $(P$-value $=0.66$ at $\alpha=0.05)$; therefore, its performance resulted in a COD removal of about $60 \%$ for an influent ammonium nitrogen up to $217 \mathrm{mg} \mathrm{L}^{-1}$.

For the same range of influent ammonium concentration (up to $200 \mathrm{mg} \mathrm{L}^{-1}$ ), the ANOVA results showed that the different performances of the GSBR and the ASBR regarding COD removal were statistically significant $(P$-value $=0.02$ at $\alpha=0.05)$.

For an influent ammonium nitrogen concentration in the range of $200 \mathrm{mg} \mathrm{L}^{-1}$, the ANOVA results showed that the different performances exhibited by the two reactors regarding COD removal were statistically significant (P-value $=1.4 \times 10^{-6}$ at $\left.\alpha=0.05\right)$.

\section{Nutrients removal}

\section{Nitrogen removal}

Results from measures of nitrogen concentration in the reactors influent and effluent are presented in Fig. 3. After 15 days, ammonium nitrogen removal (nitritation + nitrification) (Eq. 7) by the GSBR was already 61\% (Fig. 3a). As the biomass became adapted to the increasing influent concentrations of ammonium nitrogen, the removal efficiencies were also increased. A maximum average of ammonium removal

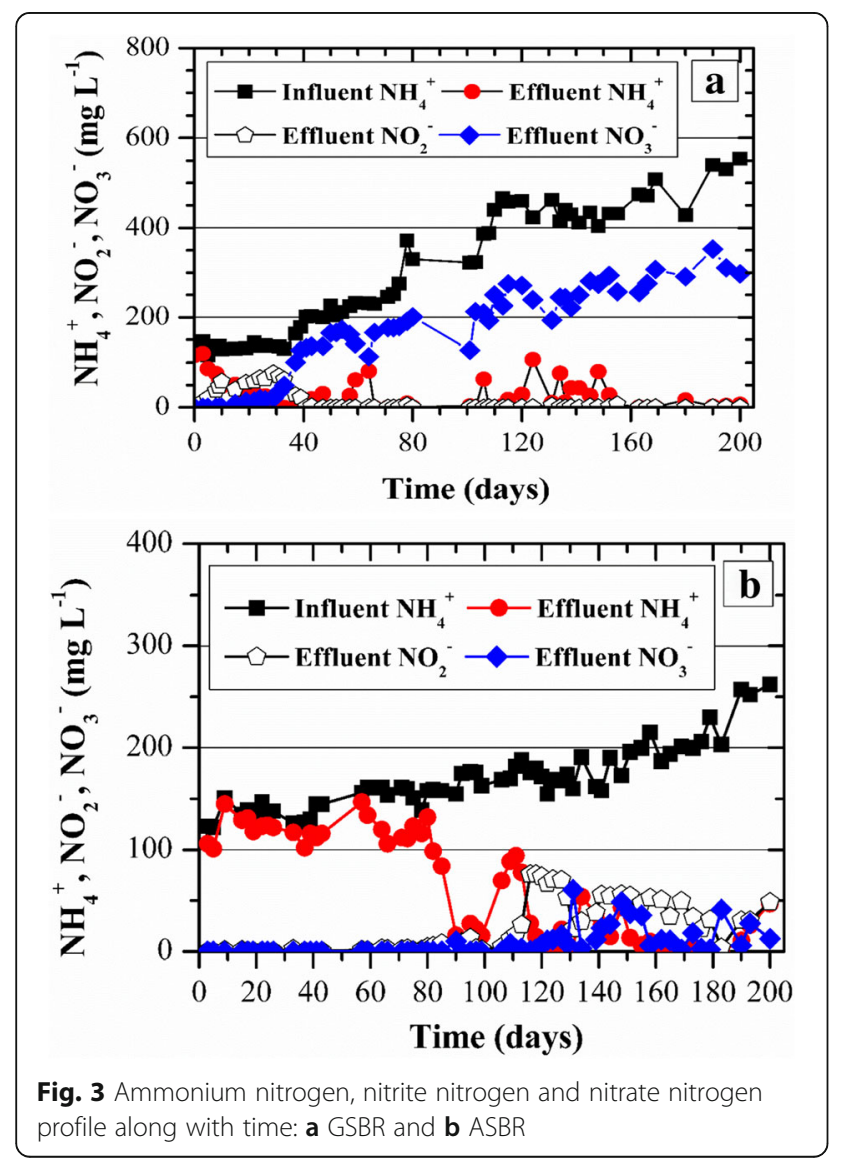

(nitritation + nitrification) of $95 \pm 7 \%$ was obtained when the GSBR was loaded with $1.39 \pm 0.14 \mathrm{~kg} \mathrm{~m}^{-3} \mathrm{~d}^{-1}$ $\left(465 \pm 46 \mathrm{mg} \mathrm{L}^{-1}\right)$. The same trend was observed for $\mathrm{TN}$, whereas the maximum removal efficiency of $39 \pm 7 \%$ was observed when the maximum nitrogen load was applied. Accordingly, SND efficiency (Eq. 6) at the last stage of the experiment was $40 \pm 7 \%$, indicating that SND was most likely the primary mechanism of TN removal, which was further assessed by kinetic tests. Fig. 3a shows that production of nitrate increased with time and its concentrations were much higher than nitrite. At the last stage of the experiment, the full nitrification efficiency was $62 \pm 9 \%$ (Eq. 3), suggesting that nitrifiers in the GSBR were not significantly inhibited by the lower influent FA concentration of $2.7 \mathrm{mg} \mathrm{L}^{-1}$ at $\mathrm{pH}$ of 7 . This result was in agreement with the previous study that nitrifiers from activated sludge were inhibited at FA concentrations of $4 \mathrm{mg} \mathrm{L}^{-1}$ [25]. However, denitrification or SND do not seem to have been fully transpired, which was further assessed during a kinetic test (Fig. 4a).

According to a kinetic test performed on day 95 (Fig. 4a), the GSBR cycle started with $221 \mathrm{mg} \mathrm{L}^{-1}$ of TN and $121 \mathrm{mg} \mathrm{L}^{-1}$ were removed at the end of it (i.e., TN removal of 55\%). The denitrification was only observed during the anoxic period. It is worth noting that despite

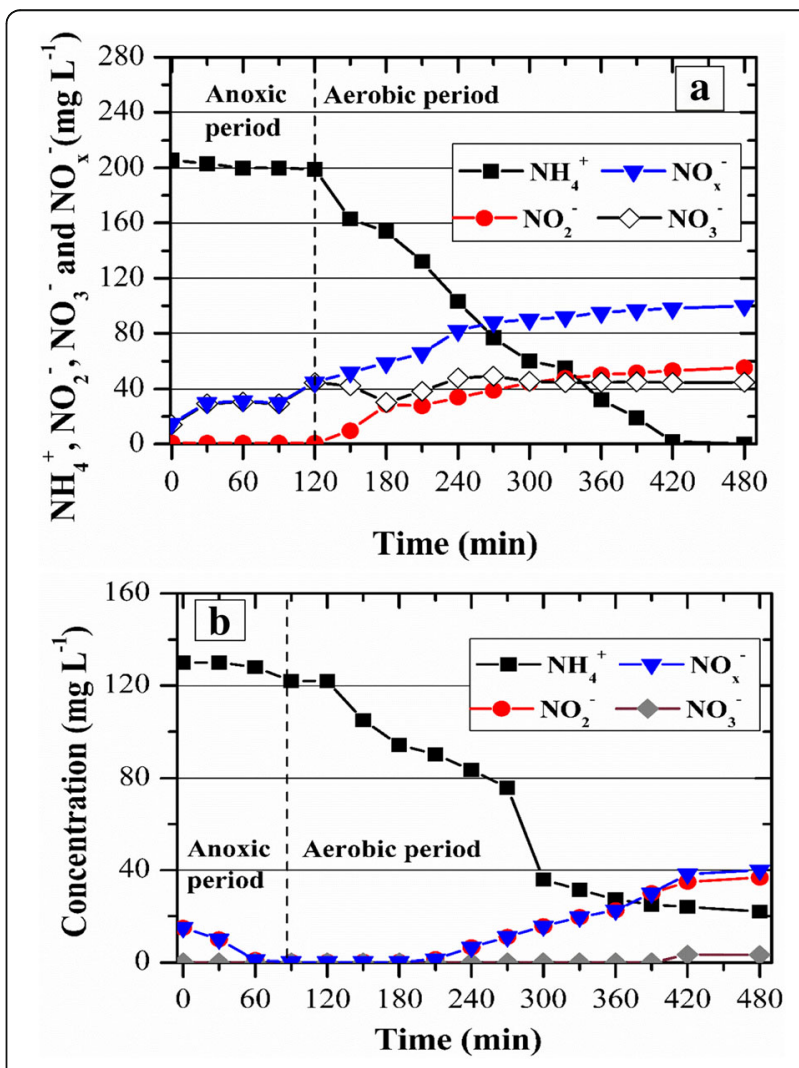

Fig. 4 Nitrogen removal during a typical cycle by $\mathbf{a}$ the GSBR and $\mathbf{b}$ the ASBR 
the availability of carbon source during the anoxic period due to feeding, the incoming influent could not have been properly mixed with all the settled biomass, which resulted in the absence of significant denitrification activity. Additionally, tannic acid could have been less susceptible to biodegradation under anaerobic/anoxic conditions rather than under aerobic conditions, which was also observed by [26]. In contrast, during the aerobic period, $121 \mathrm{mg} \mathrm{L}^{-1}$ of TN were removed via SND at an efficiency of $59 \%$. Our results were in agreement with other studies in the literature related to the treatment of ammonium-rich wastewaters $[13,27]$.

During the first 40 days, ammonium nitrogen removal (Eq. 7) by the ASBR was extremely low, $13 \pm 6 \%$ (Fig. 3b), i.e., it was almost 7 times smaller than the efficiency presented by the GSBR for the same influent ammonium concentration. As the biomass became adapted to the increasing influent concentrations of ammonium nitrogen, the removal efficiencies were also increased. A maximum average of ammonium removal (nitritation + nitrification), $96 \pm 5 \%$, was obtained when the ASBR was loaded with $0.65 \pm 0.08 \mathrm{~kg} \mathrm{~m}^{-3} \mathrm{~d}^{-1}\left(217 \pm 26 \mathrm{mg} \mathrm{L}^{-1}\right)$. The TN removal efficiencies (Eq. 7) also increased with time, reaching a maximum of $72 \pm 10 \%$ when the maximum nitrogen load was applied. Nitrate was detected at concentrations as low as $10 \mathrm{mg} \mathrm{L}^{-1}$ only after 100 days, whereas during most of the experimental duration NAR (Eq. 4) ranged from 70 to $85 \%$ (Fig. 3b). A kinetic test was performed to better investigate the mechanisms for TN removal. In contrast to the GSBR, the influent FA concentrations $(\mathrm{pH}=7.0)$ applied to the ASBR ranged from 0.8 to $1.2 \mathrm{mg} \mathrm{L}^{-1}$ (half of the FA applied to the GSBR), which interfered with the performance of nitrite oxidising bacteria (NOB) because inhibition of $\mathrm{NOB}$ occurred at FA of 0.1 to $1 \mathrm{mg} \mathrm{L}^{-1}$ [28]. Therefore, the influent FA concentration was a plausible factor of nitrite accumulation in ASBR, conforming to the previous study [29].

The kinetic test for the ASBR was performed on day 135 (Fig. 4b), when the cycle started with $145 \mathrm{mg} \mathrm{L}^{-1}$ of $\mathrm{TN}$ and $83 \mathrm{mg} \mathrm{L}^{-1}$ were removed at the end of it (i.e., TN removal of 57\%). The denitrification efficiency during the anoxic period was $18 \%$, which was likely associated to the low biodegradability of tannic acid under anaerobic/anoxic conditions, whereas the ASBR was provided with mixing in the absence of aeration. Nonetheless, during the aerobic period, $68 \mathrm{mg} \mathrm{L}^{-1}$ of TN were removed via SND at an efficiency of $63 \%$. Although this result was similar to the SND presented by the GSBR, the latter was loaded with an influent ammonium nitrogen concentration that was 1.5 times higher than GSBR.

For the same range of influent ammonium concentration (up to $200 \mathrm{mg} \mathrm{L}^{-1}$ ), the ANOVA results showed that the different performances of the GSBR and the ASBR regarding TN removal were statistically significant $(P$-value $=0.0004$ at $\alpha=0.05)$.

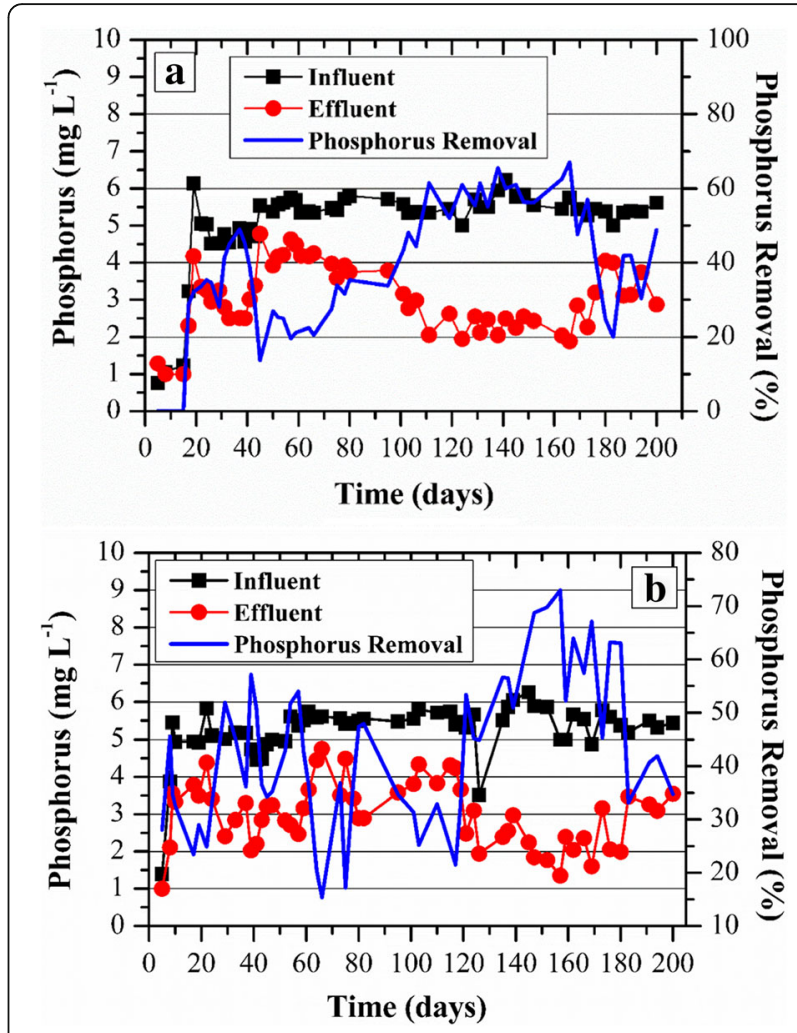

Fig. 5 Phosphorus removal (PR) along with time for a the GSBR and b the ASBR

\section{Phosphorus removal (PR)}

The influent phosphorus concentration of approximately $6 \mathrm{mg} \mathrm{L}^{-1}$ was found in both reactors (Fig. 5). However, phosphorus removal (PR) by the GSBR was gradually increased with time and reached a maximum efficiency of $54 \pm 7 \%$ (Fig. 5a). The same trend was observed for the ASBR, which presented a maximum PR of $49 \pm 14 \%$. Despite these similar average efficiencies, it was clear that the ASBR presented considerable fluctuations in comparison with the GSBR, which were much more stable.

As shown in Fig. 6a, a kinetic test was performed for the GSBR on day 95. During the anoxic period (first $90 \mathrm{~min}$ ), phosphorus was released as COD was being consumed at a ratio $\mathrm{P}_{\text {released }} / \mathrm{COD}_{\text {consumed }}$ of 0.04 . Afterward, phosphorus was assimilated by the PAO during the aerobic phase, and its removal at the end of the cycle was $34 \%$. The kinetic test for the ASBR that was performed on the 135th day showed that the ratio $\mathrm{P}_{\text {released }} /$ $\mathrm{COD}_{\text {consumed }}$ was 0.06 during the anoxic period. At the end of the aerobic phase, PR was 50\% (Fig. 6b).

These moderate PR efficiencies could have been caused by the low biodegradability of tannic acid, which has been previously assessed $[14,16]$. A previous study [30] reported that polyphosphate accumulating organisms (PAO) accounted for $70 \%$ of all bacteria from AGS 


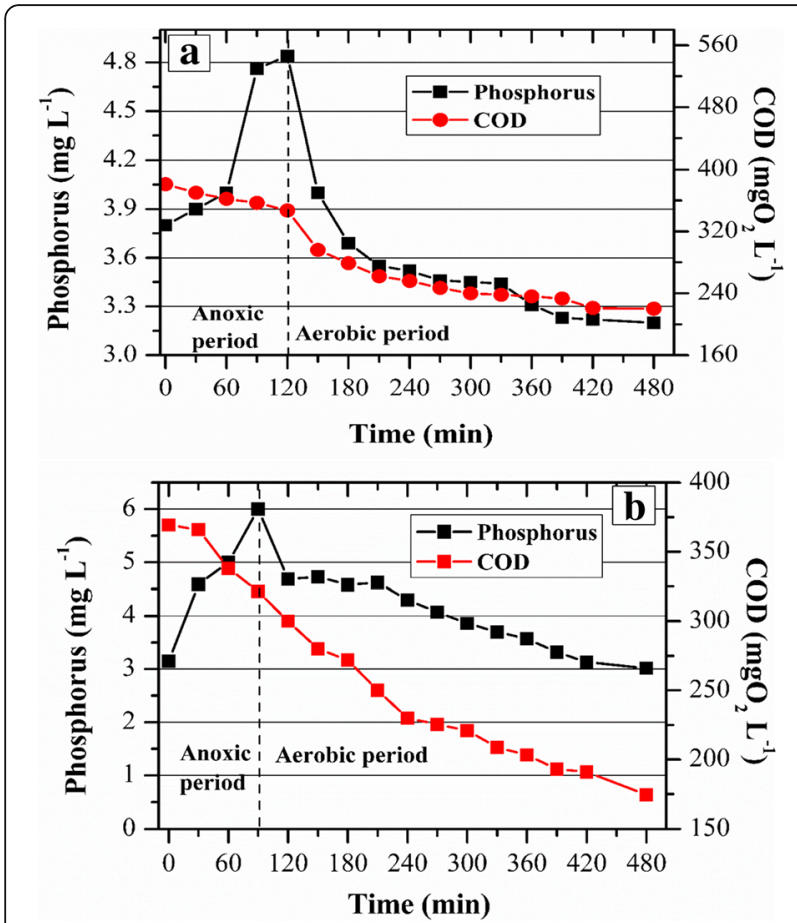

Fig. 6 Phosphorus and COD removal during a typical cycle by a the GSBR and $\mathbf{b}$ the ASBR

when the ratio $\mathrm{COD} / \mathrm{P}$ was $15: 1$, which was associated with a high phosphorus release/dissolved organic carbon uptake ratio (0.4). The opposite trend was observed when the COD/P ratio was 100:1, favoring the glycogen accumulating organisms (GAO), which compete with PAO for a carbon source. In the current research, the ratio $\mathrm{COD} / \mathrm{P}$ throughout the experiment varied from 75:1 to 100:1, probably favoring the GAO activity. Additionally, phosphorus removal could have been affected by FNA. It was recently reported [31] that at an FNA $(\mathrm{pH}=6.5)$ concentration of $1.2 \mu \mathrm{g} \mathrm{L}^{-1}$ inhibited $88 \%$ of PAO activity. In our study, FNA ( $\mathrm{pH}=6.5$ ) varied from 1 to $5 \mu \mathrm{g} \mathrm{L}^{-1}$ for the GSBR, whereas it was extremely high for the ASBR, ranging from 13 to $97 \mu \mathrm{g} \mathrm{L} \mathrm{L}^{-1}$.

For the same range of influent ammonium concentration (up to $200 \mathrm{mg} \mathrm{L}^{-1}$ ), the ANOVA results showed that the differences among the performances of the GSBR and the ASBR regarding PR were statistically insignificant $(P$-value $=0.04$ and $\alpha=0.05)$.

\section{Conclusions}

This study compared the performances of a GSBR and an ASBR in the treatment of old leachate containing different ammonium concentrations. From our results, it was concluded that the GSBR was much more efficient than the ASBR regarding the organic matter and nitrogen removal. The phosphorus removal efficiency was similar for both reactors. The granular biomass could tolerate influent ammonium concentrations 1.5 times higher than those applied to the ASBR. Although the GSBR was exposed to higher FA concentrations than the ASBR, no nitrite accumulation was observed. Further investigations should be addressed, especially with a focus on improving SND and phosphorus removal efficiencies; however, the use of AGS should be encouraged for a high-strength wastewater such as old landfill leachate.

\section{Abbreviations}

AGS: Aerobic granular sludge; AOPs: Advanced oxidation processes; ASBR: Activated sludge sequencing batch reactor; BOD: Biological oxygen demand; COD: Chemical oxygen demand; DE: Denitrification efficiency; EPS: Extracellular polymeric substances; FA: Free-ammonia; FNA: Free-nitrous acid; GSBR: Granular sludge sequencing batch reactor; MLSS: Mixed liquor suspended solids; MLVSS: Mixed liquor volatile suspended solids; MSW: Municipal solid waste; NAR: Nitrite accumulation rate; NOB: Nitrite oxidizing bacteria; PAO: Poly-phosphate accumulating organisms; PN: Protein; PR: Phosphorus removal; PS: Polysaccharide; rbCOD: Ready biodegradable chemical oxygen demand; SBR: Sequencing batch reactor; SCOD: Soluble chemical oxygen demand; SRT: Sludge retention time; SVI: Sludge volum index; TAN: Total amminiacal nitrogen; TN: Total nitrogen; TP: Total phosphorus; VFA: Volatile fatty acid

\section{Acknowledgements}

We would like to acknowledge the financial support from Natural Sciences and Engineering Research Council of Canada (RGPIN-2014-05510). Fernanda M. Ferraz would like to thank CNPq - Brazilian Ministry of Science,

Technology and Inovation (grant number 203208/2014-5) for a post-doctoral scholarship.

\section{Funding}

This work was financial supported by Natural Sciences and Engineering Research Council of Canada (RGPIN-2014-05510).

\section{Availability of data and materials}

The datasets used and/or analysed during the current study are available from the corresponding author on reasonable request.

\section{Authors' contributions}

Study conception and design: QY. Acquisition of data: YR. Analysis and interpretation of data: YR, FF, AJK, QY. Drafting of manuscript: YR, FF. Critical revision: AJK, QY. All authors read and approved the final manuscript.

Ethics approval and consent to participate

Not Applicable.

\section{Consent for publication}

Not Applicable.

\section{Competing interests}

The authors declares that they have no competing interests.

\section{Publisher's Note}

Springer Nature remains neutral with regard to jurisdictional claims in published maps and institutional affiliations.

\section{Author details}

'Department if Civil Engineering, University of Manitoba, 15 Gillson St., Winnipeg, MB R3T 5V6, Canada. 'Department of Hydraulics and Sanitation, University of Sao Paulo, Av. Trabalhador Sao-Carlense, 400, Sao Carlos, SP 13566-590, Brazil. 
Received: 27 July 2017 Accepted: 31 October 2017

Published online: 09 November 2017

\section{References}

1. Renou S, Givaudan JG, Poulain S, Dirassouyan F, Moulin P. Landfill leachate treatment: review and opportunity. J Hazard Mater. 2008;150:468-93. https://doi.org/10.1016/j.jhazmat.2007.09.077

2. Zhu R, Wang S, Li J, Wang K, Miao L, Ma B, Peng Y. Biological nitrogen removal from landfill leachate using anaerobic- aerobic process: Denitritation via organics in raw leachate and intracellular storage polymers of microorganisms. Bioresour Technol. 2013;128:401-8. https://doi.org/10. 1016/j.biortech.2012.10.063

3. Brennan RB, Clifford E, Devroedt C, Morrison L, Healy MG. Treatment of landfill leachate in municipal wastewater treatment plants and impacts on effluent ammonium concentrations. J Environ Manag. 2017;188:64-72. https://doi.org/10.1016/j.jenvman.2016.11.055.

4. Deng Y, Ezyske CM. Sulfate radical-advanced oxidation process (SR-AOP) for simultaneous removal of refractory organic contaminants and ammonia in landfill leachate. Water Res. 2011;45:6189-94. https://doi.org/10.1016/j. watres.2011.09.015.

5. Moravia WG, Amaral MCS, Lange LC. Evaluation of landfill leachate treatment by advanced oxidative processy by Fenton's reagent combined with membrane separation system. Waste Manag. 2013;33:89-101.

6. Chemlal R, Azzouz L, Kernani R, Abdi N, Lounici H, Grib H, Mameri N, Drouiche N. Combination of advanced oxidation and biological processes for the landfill leachate treatment. Ecol Eng. 2014;73:281-9. https://doi.org/ 10.1016/j.ecoleng.2014.09.043

7. Yuan Q, Jia H, Poveda M. Study on the effect of landfill leachate on nutrient removal from municipal wastewater. J Environ Sci. 2016;43:153-8. https:// doi.org/10.1016/j.jes.2015.10.023.

8. Campos R, Ferraz F, Vieira E, Povinelli J. Aerobic co-treatment of landfil leachate and domestic wastewater-are slowly biodegradable organics removed or simply diluted? Water Sci Technol. 2014;70:1941-7. https://doi. org/10.2166/wst.2014.439.

9. Ferraz FM, Bruni AT, Povinelli J, Vieira EM. Leachate/domestic wastewater aerobic co- treatment: a pilot- scale study using multivariate analysis. J Environ Manag. 2016;166:414-9. https://doi.org/10.1016/j.jenvman.2015.10.034

10. El-Gohary FA, Kamel G. Characterization and biological treatment of pre-treated landfill leachate. Ecol Eng. 2016;94:268-74. https://doi.org/10. 1016/j.ecoleng.2016.05.074.

11. Lotito AM, Fratino U, Mancini A, Bergna G, Di laconi C. Effective aerobic granular sludge treatment of a real dyeing textile wastewater. Int Biodeterior Biodegradation. 2012;69:62-8. https://doi.org/10.1016/j. ibiod.2012.01.004

12. Pronk M, de Kreuk MK, de Bruin B, Kamminga P, Kleerebezem R, van Loosdrecht MCM. Full scale performance of the aerobic granular sludge process for sewage treatment. Water Res. 2015;84:207-17. https://doi.org/10. 1016/j.watres.2015.07.011

13. Wei Y, Ji M, Li R, Qin F. Organic and nitrogen removal from landfill leachate in aerobic granular sludge sequencing batch reactors. Waste Manag. 2012; 32:448. https://doi.org/10.1016/j.wasman.2011.10.008

14. Beaven Richard, Potter Hugh, Powrie William, Simoes Ana, Smallman Dave and S. Anne. Attenuation of organic contaminants in leachate by mineral landfill liners. 2009. http://www.wmrg.soton.ac.uk/SCHO0609BQEG-e-e.pdf. Accessed 15 Oct 2017

15. Vangulck JF, Rowe RK. Evolution of clog formation with time in columns permeated with synthetic landfill leachate. J Contam Hydrol. 2004;75:11539. https://doi.org/10.1016/j.jconhyd.2004.06.001.

16. Munz G, Angelis DD, Gori R, Mori G, Casarci M, Lubello C. The role of tannins in conventional and membrane treatment of tannery wastewater. J Hazard Mater. 2009;164:733-9. https://doi.org/10.1016/j.jhazmat.2008.08.070.

17. APHA. Standard methods for the examination of water and wastewater. In: American public health association/American Water Works Association/water environment federation. 21st ed. Washington: APHA/AWWAMEF; 2005.

18. Adav SS, Lee D-J. Extraction of extracellular polymeric substances from aerobic granule with compact interior structure. J Hazard Mater. 2008;154: 1120-6. https://doi.org/10.1016/j.jhazmat.2007.11.058.

19. DuBois M, Gilles KA, Hamilton JK, Rebers PA, Smith F. Colorimetric method for determination of sugars and related substances. Anal Chem. 1956;28(3): 350-6. https://doi.org/10.1021/ac60111a017.
20. Anthonisen AC, Loehr RC, Prakasam TBS, Srinath EG. Inhibition of nitrification by ammonia and nitrous acid. J Water Pollut Control Fed. 1976;48(5):835-52

21. Xu Z-Y, Zeng G-M, Yang Z-H, Xiao Y, Cao M, Sun H-S, Ji L, Chen Y. Biological treatment of landfill leachate with the integration of partial nitrification, anaerobic ammonium oxidation and heterotrophic denitrification. Bioresour Technol. 2010;101:79-86. https://doi.org/10.1016/j.biortech.2009.07.082.

22. Zeng RJ, Lemaire R, Yuan Z, Keller J. Simultaneous nitrification, denitrification, and phosphorus removal in a lab- scale sequencing batch reactor. Biotechnol Bioeng. 2003;84:170-8. https://doi.org/10.1002/bit.10744.

23. Metcalf and Eddy. Wastewater engineering : treatment and reuse. 4th ed./ rev. by George Tchobanoglous, Franklin L. Burton, H. David Stensel. Boston: McGraw-Hill, 2003.

24. Sheng GP, Yu HQ, Li XY. Extracellular polymeric substances (EPS) of microbial aggregates in biological wastewater treatment systems: review. Biotechnol Adv. 2010;28(6):882-94.

25. Yang S-F, Tay J-H, Liu Y. Inhibition of free ammonia to the formation of aerobic granules. Biochem Eng J. 2004;17:41-8. https://doi.org/10.1016/ S1369-703X(03)00122-0.

26. Ramos C, Suárez-Ojeda ME, Carrera J. Biodegradation of a high-strength wastewater containing a mixture of ammonium, aromatic compounds and salts with simultaneous nitritation in an aerobic granular reactor. Process Biochem. 2016;51:399-407. https://doi.org/10.1016/j.procbio.2015.12.020.

27. Yan L, Liu Y, Wen Y, Ren Y, Hao G, Zhang Y. Role and significance of extracellular polymeric substances from granular sludge for simultaneous removal of organic matter and ammonia nitrogen. Bioresour Technol. 2015; 179:460-6. https://doi.org/10.1016/j.biortech.2014.12.042.

28. Yun H-J, Kim D-J. Nitrite accumulation characteristics of high strength ammonia wastewater in an autotrophic nitrifying biofilm reactor. J Chem Technol Biotechnol. 2003;78(4):377-83. doi:10.1002/jctb.751.

29. Cydzik-Kwiatkowska A, Zielińska M, Bernat K, Wojnowska-Baryła I, Truchan T. Treatment of high- ammonium anaerobic digester supernatant by aerobic granular sludge and ultrafiltration processes. Chemosphere. 2013;90:220815. https://doi.org/10.1016/j.chemosphere.2012.09.072.

30. Muszyński A, Miłobędzka A. The effects of carbon/phosphorus ratio on polyphosphate- and glycogen-accumulating organisms in aerobic granular sludge. Int J Environ Sci Technol. 2015;12:3053-60. https://doi.org/10.1007/ s13762-015-0828-8.

31. Jabari P, Munz G, Yuan Q, Oleszkiewicz JA. Free nitrous acid inhibition of biological phosphorus removal in integrated fixed-film activated sludge (IFAS) system. Chem Eng J. 2016;287:38-46. https://doi.org/10.1016/j.cej. 2015.10.117.

\section{Submit your next manuscript to BioMed Central and we will help you at every step:}

- We accept pre-submission inquiries

- Our selector tool helps you to find the most relevant journal

- We provide round the clock customer support

- Convenient online submission

- Thorough peer review

- Inclusion in PubMed and all major indexing services

- Maximum visibility for your research

Submit your manuscript at www.biomedcentral.com/submit
) Biomed Central 